\title{
IDENTIFICATION OF ANIMAL SPECIES AND FOREIGN TISSUES IN READY-TO-SELL FRESH PROCESSED MEAT PRODUCTS
}

\author{
O. Cetin ${ }^{a}$, E.B. Bingola*, E. Civan ${ }^{\text {b }}$, S.I. TurgaY ${ }^{\mathrm{c}}$ and O. Ergun ${ }^{\mathrm{a}}$

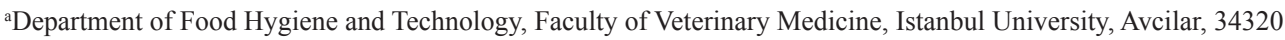 \\ Istanbul. Turkey \\ ${ }^{\text {b} M u n i c i p a l i t y ~ o f ~ G u ̈ n g o ̈ r e n, ~ D i r e c t o r a t e s ~ o f ~ V e t e r i n a r y ~ A f f a i r s, ~ G u ̈ n g o ̈ r e n, ~} 34164$ Istanbul. Turkey \\ ${ }^{\mathrm{c}}$ Academic Hygiene KGaA, Training, Audit and Consulting Services, Kustepe Mahallesi, Tomurcuk Sokak, Izmen \\ Sitesi, Sisli, 34387 Istanbul. Turkey
}

(Received: 10 July 2014; accepted: 5 November 2014)

\begin{abstract}
The demand for ready-to-eat meat products has recently increased, and routine controls are inevitable to provide food safety. Therefore, a total of 250 fresh processed beef meat products collected from local markets and restaurants in the districts of Istanbul mostly with low purchasing power were investigated by histological and biomolecular methods. Chicken tissue was found in $62(24.8 \%)$ of the analysed samples and horse tissue was found in $2(0.8 \%)$ samples, while pork tissue was not detected. Additionally, foreign tissues were detected in 70 (28\%) of 250 samples. PCR assays combined with histological examinations can be used as an important method in establishing food safety by determining the deliberate or accidental adulterations of meat products.
\end{abstract}

Keywords: animal species, foreign tissue, PCR assay, histological evaluation, food safety

As one of the most important foods for human beings, meat contains high amounts of biologically relevant proteins that are composed of exogenous amino acids. The consumption of meat and meat products has increased with modern manufacturing techniques (GüRBüZ, 2009). Compared with other foods, high quality meat and meat products are expensive, suggesting that the demand and consumption of meat will vary according to the economic status of the consumers, the price of raw meat, the production methods, and the storage requirements (KARAKUS et al., 2008; GÜRBÜZ, 2009).

Depending upon the specific processing technique, cutting meat into pieces can shorten the shelf-life of the products, increasing the potential risks for adverse consumer health effects (BAŞKAYA et al., 2004; Cetin et al., 2010). Turkish standards (TFC, 2012) specify the structural elements required to be present in the prepared meat mixtures (skeletal muscle tissue and a small amount of fat). As the addition of undesired tissues, including inedible parts with high amounts of fat, bones, cartilage, horn, and nails is prohibited, these tissues can negatively affect the structural elements of the manufactured products and can lead to unfair competition and profit (BAŞKAYA et al., 2004; Cetin et al., 2010). Manufacturers of meat products should denote clear and accurate information on the description and/or labelling of the food products to ensure consumer rights (Woolfe \& Primrose, 2004).

Multiple techniques have been developed to detect and identify the types of biological species during the last decade. Protein-based methods, like SDS-PAGE, ELISA, or HPLC, have been used for the detection of food fraud, but these techniques have several inherent

\footnotetext{
* To whom correspondence should be addressed. Phone: +90-212-4737070; fax: +90-212-4737241; e-mail: bingolb@istanbul.edu.tr
} 
problems, including insufficient specificity, application problems, and high cost (ILHAK \& Arslan, 2007; ABdel-Rahman et al., 2009). In recent years, besides biomolecular methods, specific and fast analysis based on peptidomic methods could be employed as effective tools for species identification in meat products (VON BARGEN et al., 2013; MonTOwsKa et al., 2014).

The aim of this study was to investigate the types of animal species and foreign tissues in ready-to-sell fresh processed beef meat products that were sold in local markets and restaurants in Istanbul, Turkey to determine the extent of product imitation and adulteration.

\section{Materials and methods}

A total of 250 fresh processed beef meat products ( 90 ground meat, 40 meatballs, 50 lahmacun mixtures, 40 kebabs, and 30 döner kebabs) that were collected from local markets and restaurants in various districts of Istanbul mostly with low purchasing power $(68 \%$ of the samples) during August 2012-February 2013 were examined for the type of notifications on the labels and the assessment of adulteration by histological and multiplex PCR methods.

\subsection{Sample preparation and DNA extraction}

DNA isolates of meat samples and positive controls that were obtained from commercial sources (fresh horse, chicken, and pork raw meats) were extracted according to the protocol of the manufacturer (High Pure PCR Template Preparation Kit, Roche Diagnostics GmbH, Roche Applied Science, Mannheim, Germany). Extracted DNA concentrations of the isolates were quantified by measuring UV absorption at $260 \mathrm{~nm}$; then all extracts were stored at $-20{ }^{\circ} \mathrm{C}$ until using in the PCR procedures. Furthermore, to evaluate the test sensitivity, binary mixtures of meats were prepared by mixing each of horse, chicken, and pork meats with beef meat at different rates $(0,0.1,0.5,1$, and $5 \%)$. The varying proportions of mixed meat were then subjected to DNA isolation and subsequent PCR assay. The results of the PCR reactions for the binary meat mixtures showed that the detection limit of the meat species in beef meat was $0.5 \%$ for horse, chicken, and pork meat (Fig. 1). Also, the calculated mean DNA concentration in extracts was found to be $106.45 \mathrm{ng}^{\mathrm{l}} \mathrm{l}^{-1}$ and mean purity ratio was 1.896 .

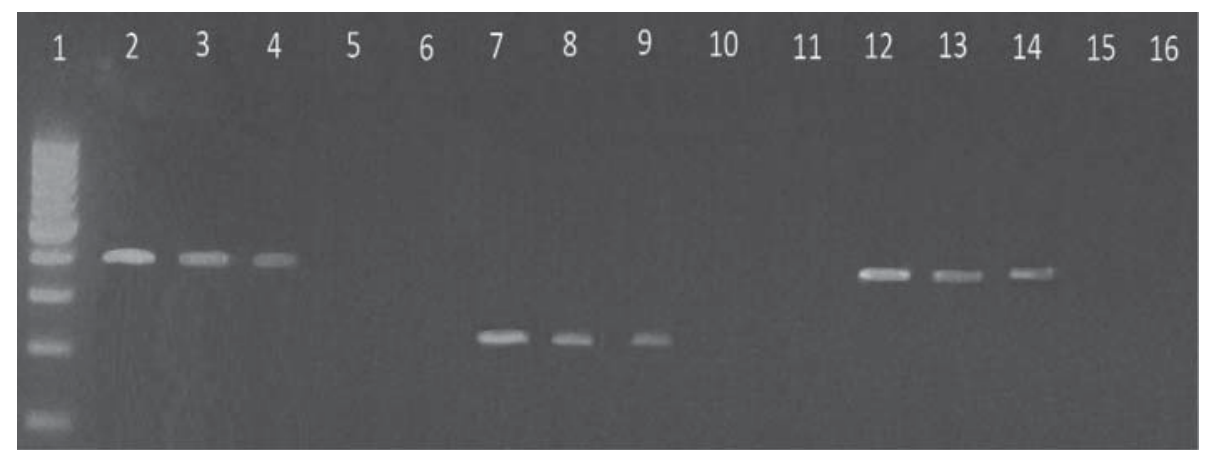

Fig. 1. The result of sensitivity of PCR assays for the binary meat mixtures prepared either by mixing horse, chicken, and pork meats with beef meat. 1: Molecular marker (100 bp); 2: 5\% horse; 3: 1\% horse; 4: $0.5 \%$ horse; 5: $0.1 \%$ horse; $6: 0 \%$ horse; $7: 5 \%$ chicken; $8: 1 \%$ chicken; $9: 0.5 \%$ chicken; $10: 0.1 \%$ chicken; $11: 0 \%$ chicken; 12: $5 \%$ pork, $13: 1 \%$ pork; $14: 0.5 \%$ pork, $15: 0.1 \%$ pork; $16: 0 \%$ pork 


\subsection{Primer designs and PCR procedure}

The primers were designed from published sequences of pig, chicken, and horse mitochondrial cytochrome b genes and are given in Table 1. Each PCR mixture had a volume of $50 \mu \mathrm{l}$, consisting of $2 \mu \mathrm{l}$ of each primer ( $20 \mathrm{pmol}$ each), $10 \mu \mathrm{l} 5 \mathrm{X}$ buffer (Kapabiosystems, $1.5 \mathrm{mM}$ Mg final concentration), $3 \mu 125 \mathrm{mM} \mathrm{MgCl}, 200 \mu \mathrm{M} \mathrm{dNTP}$ mixture (TaKaRA), $0.125 \mu \mathrm{l} \mathrm{Taq}$ polymerase $(5 \mathrm{u} / \mu \mathrm{l}-\mathrm{Kapa})$, and $250 \mathrm{ng}$ template DNA. The mixtures were processed in a thermal cycler. After an initial denaturation step at $95^{\circ} \mathrm{C}$ for $5 \mathrm{~min}$, a total of 35 cycles $(0.5$ min at $94{ }^{\circ} \mathrm{C}, 0.5 \mathrm{~min}$ at $50{ }^{\circ} \mathrm{C}, 0.5 \mathrm{~min}$ at $\left.72{ }^{\circ} \mathrm{C}\right)$ with a final synthesis step $\left(5 \mathrm{~min}\right.$ at $\left.72{ }^{\circ} \mathrm{C}\right)$ were used to process the samples. The PCR products were stored at $4{ }^{\circ} \mathrm{C}$ until used in the electrophoretic separation procedures (MATSUNAGA et al., 1999).

Table 1. Designed primers for animal species

\begin{tabular}{|c|c|c|c|}
\hline $\begin{array}{l}\text { Animal } \\
\text { species }\end{array}$ & Primers & $\begin{array}{l}\text { Amplicon } \\
\text { size }\end{array}$ & Reference \\
\hline Pork & $\begin{array}{l}\text { F -5'-GACCTCCCAGCTCCATCAAACATCTCATCTTGAT- } \\
\text { GAAA-3' } \\
\text { R-5'-GCTGATAGTAGATTTGTGATGACCGTA-3' }\end{array}$ & 398 bp & $\begin{array}{l}\text { MATSUNAGA et al. } \\
\text { (1999) }\end{array}$ \\
\hline Horse & $\begin{array}{l}\text { F -5'-GACCTCCCAGCTCCATCAAACATCTCATCTTGAT- } \\
\text { GAAA-3' } \\
\text { R-5'CTCAGATTCACTCGACGAGGGTAGTA-3' }\end{array}$ & 439 bp & $\begin{array}{l}\text { MATSUNAGA et al. } \\
\text { (1999) }\end{array}$ \\
\hline Chicken & $\begin{array}{l}\text { F -5'-GACCTCCCAGCTCCATCAAACATCTCATCTTGAT- } \\
\text { GAAA-3' } \\
\text { R-5'-AAGATACAGATGAAGAAGAATGAGGCG-3' }\end{array}$ & $227 \mathrm{bp}$ & $\begin{array}{l}\text { MATSUNAGA et al. } \\
\text { (1999) }\end{array}$ \\
\hline
\end{tabular}

\subsection{Electrophoresis}

For the electrophoresis procedure, $10 \mu \mathrm{l}$ of each PCR product with $2 \mu \mathrm{l} 6 \mathrm{X}$ loading buffer were loaded onto a $1.5 \%$ agarose gel, stained with ethidium bromide, and operated for $30 \mathrm{~min}$ at $100 \mathrm{~V}$. Specific bands were illuminated using UV transillumination. The primers generated species-specific fragments of 439, 227, and 398 bp for horse, chicken, and porcine tissues, respectively.

\subsection{Histological analyses}

All samples were homogenised separately, and $25 \pm 5 \mathrm{~g}$ pieces from each sample were placed into Erlenmeyer flasks, followed by an addition of a 1:1 ratio acetone/ether mixture to each sample. The samples were held in a fume hood for 1 hour. The acetone/ether mixture was then filtered, and this procedure was repeated 3 times. The last filtrate of each sample was dried on the filter papers. Glycerine was added to the dried samples to provide moistness, and the samples were held for $10-15 \mathrm{~min}$. A $10 \%$ gelatine solution prepared at $80^{\circ} \mathrm{C}$ was then added. Each mixture was stirred, producing a slurry appearance. The mixtures were then centrifuged for $10 \mathrm{~min}$ at 3000 r.p.m. After the centrifugation process, the samples were stored overnight in the refrigerator. The edges of the tubes were cut, and the gelatine parts of the mixture were removed from the samples. The remaining tissue parts were divided into $2-3$ pieces and the pieces were fixed with $10 \%$ formaldehyde for 24 hours. At the end of the fixation period, the samples were washed under continuously flowing water for 12 hours to 
completely remove the formaldehyde. The samples were cut with a cryostat (Mikrom HM500OM, Germany) to produce slides with thicknesses of 10-12 $\mu \mathrm{m}$. Crossman's triple staining procedure was used with each sample (YILDIZ et al., 2004). At least 10 slides were prepared for each sample with the slides examined using a microscope (Olympus CX31, Japan) and photographed.

\section{Results and discussion}

To identify the quality attributes of the products used in this study, 250 fresh processed beef meat products were analysed for product characteristics and possible adulterations. The results indicated that chicken tissue was present in 62 of the analysed samples $(24.8 \%)$ with horse tissue in 2 samples $(0.8 \%)$. Pork tissue was not found in any of the meat samples (Table 2), while foreign tissues were determined in 70 (28\%) of 250 samples (Table 3).

Table 2. Determination of tissue types of the meat samples using biogenetic evaluation $(\mathrm{n}=250)$

\begin{tabular}{lccl}
\hline Type of tissue & $\begin{array}{c}\text { Number of positive } \\
\text { samples }\end{array}$ & $\begin{array}{c}\text { Percentage of positive } \\
\text { samples }(\%)\end{array}$ & $\begin{array}{l}\text { Number of products determined according } \\
\text { to the type of tissue }\end{array}$ \\
\hline Chicken & 62 & 24.8 & $\begin{array}{l}\text { Kebab (18), döner kebab (5), meatball (14), } \\
\text { ground meat (13), Lahmacun mixture (12) }\end{array}$ \\
Horse & 2 & 0.8 & Meatball (1), kebab (1) \\
Pork & - & 0 & - \\
\hline
\end{tabular}

Table 3. Types of foreign tissues found in fresh processed beef products using histological evaluation $(\mathrm{n}=250)$

\begin{tabular}{lccl}
\hline $\begin{array}{l}\text { Name of the } \\
\text { product }\end{array}$ & $\begin{array}{c}\text { Number of positive } \\
\text { samples }\end{array}$ & $\begin{array}{c}\text { Percentage of positive } \\
\text { samples }(\%)\end{array}$ & Adulterated tissues \\
\hline $\begin{array}{l}\text { Ground meat } \\
\text { Meatball }\end{array}$ & 19 & 27.14 & Heart, lung, skin, gizzards, liver \\
$\begin{array}{l}\text { Lahmacun } \\
\text { mixture }\end{array}$ & 8 & 11.42 & Kidney, liver, gizzards, heart, bones/cartilage \\
$\begin{array}{l}\text { Döner kebab } \\
\text { Kebabs }\end{array}$ & 10 & 28.57 & Kidney, liver, gizzards, heart, lung \\
$\begin{array}{l}\text { Detected } \\
\text { foreign tissues }\end{array}$ & 13 & 14.28 & Bones/cartilage, kidney, gizzards \\
\hline
\end{tabular}

Examining the samples for multiple possible contaminants, minced meat and lahmacun mixtures were determined to be the most adulterated products (Fig. 2A), with chicken gizzards, bones, and cartilage tissue, which were the most frequently used tissues in the contaminants (Fig. 2B). Foreign tissues originating from poultry were observed in 30 of 70 samples (12\%), while the remaining 40 samples (16\%) contained cattle based foreign tissues. The foreign tissues included kidneys (17.14\%), liver (14.28\%), skin (4.28\%), heart (8.57\%), lung $(10 \%)$, bones/cartilage $(20 \%)$, and gizzards $(25.71 \%)$. Samples containing more than one foreign tissue were also detected in the analysed meat products. The total percentage of meat samples containing two foreign tissues was $27.12 \%$, with $7.13 \%$ of the meat samples 
containing three foreign tissues. Combinations of heart and lung, liver and gizzard, skin and gizzard, kidneys and gizzard, kidneys and bones/cartilages were found in $4(5.71 \%), 5$ (7.14\%), $3(4.28 \%), 3(4.28 \%)$, and $4(5.71 \%)$ samples, respectively. A combination of gizzard, kidneys, and bones/cartilage was found in 3 samples (4.28\%), the combination of liver, kidneys and bones/cartilage detected in 2 samples (2.85\%).
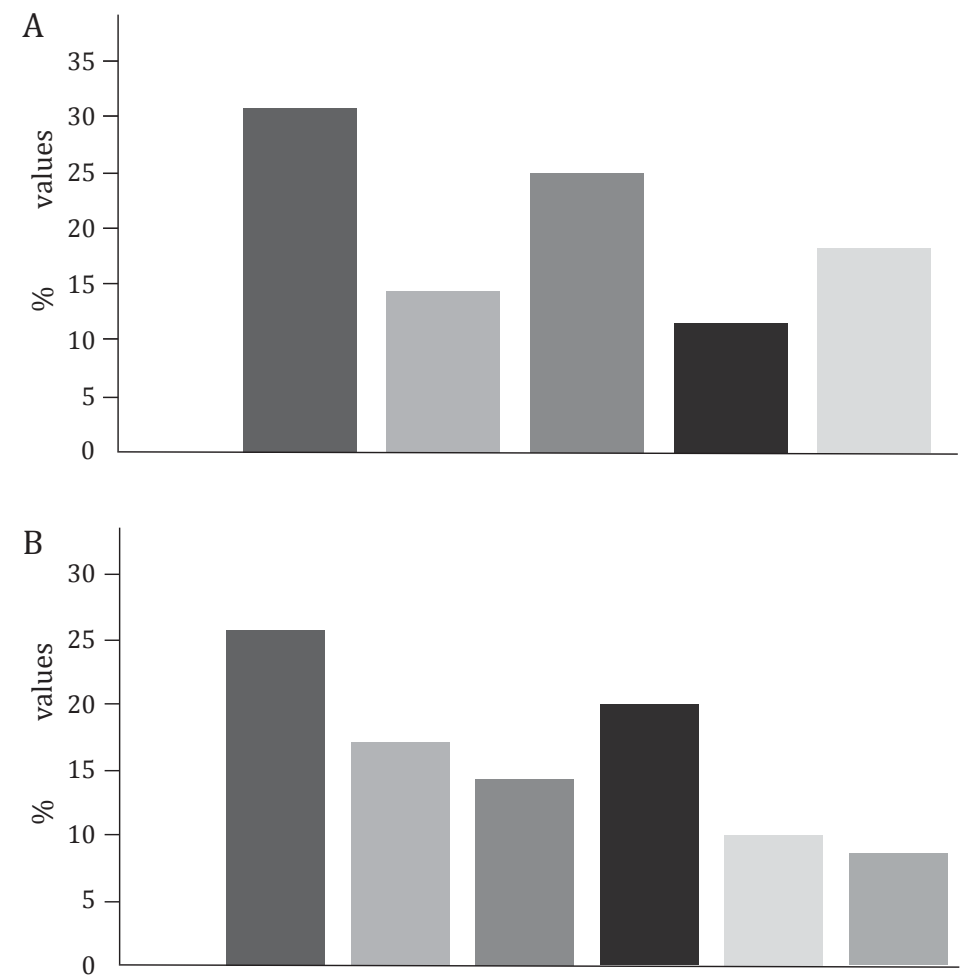

Fig. 2. Distribution of the imitated and adulterated products (A) $(\%, n=104)$ and the detected foreign tissues (B) $(\%, n=70)$

A: ㅁ: Ground meat; ㅍ: meatball; ㅍ: lahmacun mixture; $\mathbf{\square}:$ döner kebab; : kebabs

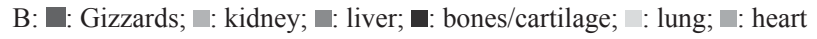

BAŞKAYA and co-workers (2004) reported that cartilage tissue and organs belonging to the alimentary canal were found in 3 of 27 ready-to-sell minced meat samples in Ankara. Similarly, YILDIZ and co-workers (2004) reported little and very little inedible tissue traces in 4 and 2 of 75 ready-to-sell meatballs collected in Istanbul, respectively. CETIN and co-workers (2010) reported that 21 of the 127 ready-to-sell minced meat samples contained high amounts of $\mathrm{Ca}^{++}$, suggesting that the high $\mathrm{Ca}^{++}$amounts may indicate the addition of non-meat materials, such as ground bone fragments and mechanically deboned meat.

Offal, such as chicken liver and lung, can be quite inexpensive. Presence of these materials in meat products points out the adulteration and suggests the existence of unfair competition in the market. Examples of foreign tissues examined histologically and biogenetically in this study are shown in Figures 3 and 4. 
A

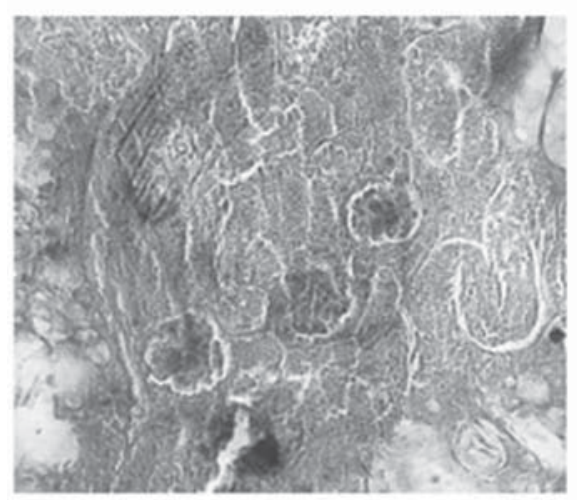

$\mathrm{C}$

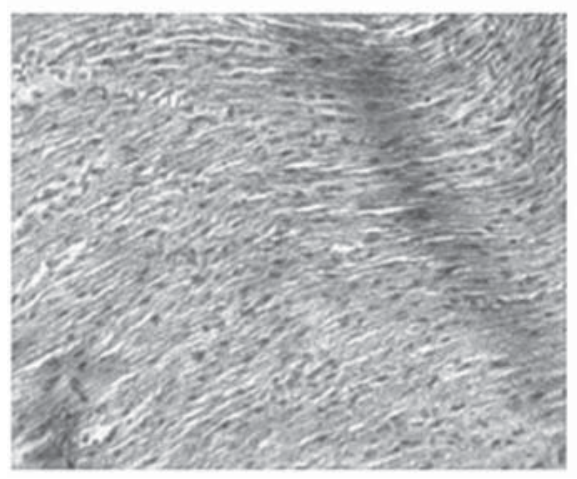

B

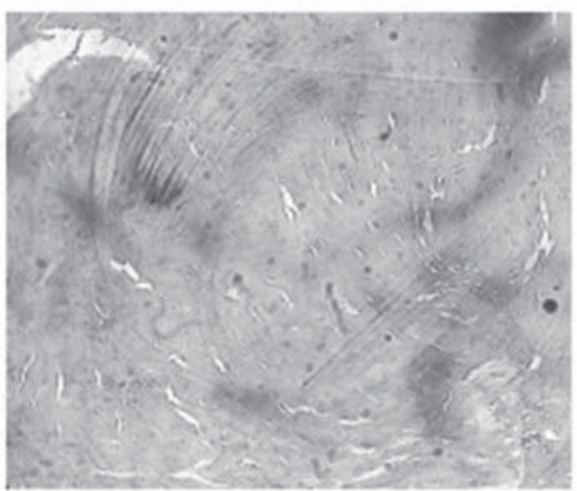

D

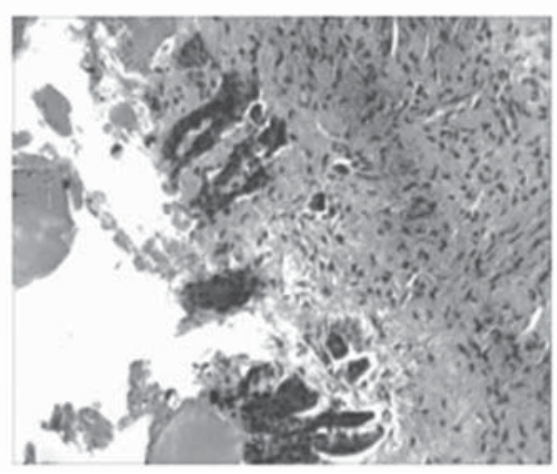

Fig. 3. Histological images of the foreign tissues detected in fresh processed beef products A: Kidney tissue; B: cartilage tissue; C: heart tissue; D: gizzard tissue

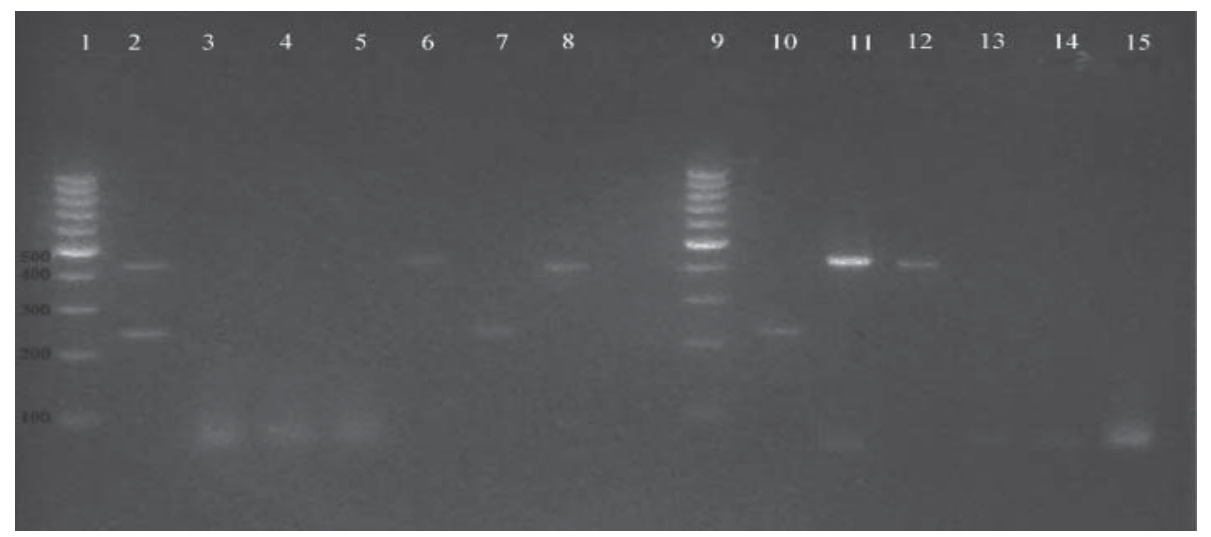

Fig. 4. Agarose gel electrophoresis of the PCR products amplified from the meat based samples. 1: Molecular marker (100 bp); 2: horse (439 bp) and chicken (227 bp) positive control; 3: horse negative control; 4: chicken negative control; 5: pork negative control; 6: horse positive control (439 bp); 7: chicken positive control (227 bp); 8: pork positive control (398 bp); 9: molecular marker (100 bp); 10: chicken positive sample (227 bp); 11: horse positive sample (439 bp); 12: horse positive sample (439 bp); 13: chicken negative sample; 14: horse negative sample; 15: pork negative sample 
BAŞKAYA and co-workers (2004) and YILDIZ and co-workers (2004) reported that traces of horse and pork meats were detected in ready-to-sell raw minced meat and meatballs available in Turkey. CETIN and co-workers (2005) emphasized that 83 (36.8\%) of 223 analysed raw and heat processed meat products contained meat that was not reported on the labels (4 pork and 78 poultry meats). In another study performed by CETIN and co-workers (2010), no horse or pork meat was detected in 127 ready-to-sell minced meats; however, 4 samples contained poultry and 8 samples contained lamb. For economic, religious, and health reasons, the identification of animal tissues in meat products is essential in protecting the consumer from both illegal competition and undesirable adulterations (Kesmen et al., 2007). Multiplex PCR is a rapid and affordable method to identify the origin of meat type. Especially, by using species-specific primers, muscle tissues from multiple animal species could be easily detected in meat products even at low levels (less than 1\% in meat mixtures) (PARTIS et al., 2000; MANE et al., 2009). ÖZPINAR and co-workers (2013) determined that 39 out of 73 meat samples were labelled incorrectly in Istanbul markets. Similarly, TÜRKYILMAZ and IRMAK (2008) reported that 18 out of 116 meat samples collected from Izmir were labelled incorrectly, containing unreported animal species, including horse flesh (9.5\%), pork (9.5\%), and chicken $(23.8 \%)$ in the sliced meats as well as pork and beef $(4.8 \%)$ and a chicken and beef mix $(9.5 \%)$ in the ground meat. GüNŞEN and co-workers (2006) emphasised that the labels on 100 meat samples collected in Istanbul and Bursa were incorrect, with errors found in 11 fermented sausages, 8 sausages, 2 raw meat samples, and 1 ground meat sample. In another study, AyAZ and co-workers (2006) reported that the adulteration ratio was 19.2\% (79/410 meat samples), and added that the sellers might have added the various animal species that were not recorded on the labels to the meat products to decrease the preparation costs. Likewise, HsieH and coworkers (2005) illustrated the situation about the fraudulent misdescription of food contents on product labels in Taiwan markets.

With legislation published on 5 December 2012 in Turkey (TFC, 2012), meat and meat products produced with meat belonging to multiple animal species are prohibited, intending to prevent the sale of meat mixtures produced from more than one animal. This legislation is also intended to encourage producers to concentrate on preventing accidental adulterations in the plants that process more than one animal species. As a result, enhanced customer safety may be achieved by avoiding product imitations and adulterations, as well as the reduction of unfair competition and revenues.

\section{Conclusions}

Food safety is a key policy priority for the Commission of the European Communities, and adulterations are forbidden in meat products (EC, 2002). Biomolecular methods appear to be precise, sensitive, and rapid techniques for routine analysis of meat to identify undesired animal species in meat products. Conscious and/or accidental contamination of foreign tissues from the same animal species, including bone and cartilage pieces, heart, kidneys, and lungs, must also be investigated with histological identification methods as a complementary examination. Thus, it can be concluded that the biomolecular and histological methods are functional tools for routine assessments of authenticity and quality of meat based products to protect the consumers from fraudulent practices of meat substitution.

The authors would like to thank Bilim Laboratuvarları (Kızılelma Caddesi No: 6 Fındıkzade, Istanbul, Turkey) for technical support on the PCR and histological analyses. 


\section{References}

Abdel-Rahman, S.M., El-Saadani, M.A., Ashry, K.M. \& Haggag, A.S. (2009): Detection of adulteration and identification of cat's, dog's, donkey's and horse's meat using species-specific PCR and PCR-RFLP techniques. Aust. J. Basic Appl. Sci., 3, 1716-1719.

Ayaz, Y., Ayaz, N.D. \& Erol, I. (2006): Detection of species in meat and meat products using enzyme-linked immunosorbent assay. J. Muscle Foods, 17(2), 214-220.

Başkaya, R., Karaca, T., Sevinç, İ., Çakmak, Ö., Yıldiz, A. \& YörüK, M. (2004): İstanbul'da Satışa Sunulan Hazır Kıymaların Histolojik, Mikrobiyolojik ve Serolojik Kalitesi (The histological, microbiological, and serological quality of ground beef marketed in Istanbul). YYU Vet. Fak. Derg., 15, 41-46.

Cetin, O., Bingol, E.B., Colak, H., Ergun, O. \& Demir, C. (2010): The microbiological, serological and chemical qualities of mincemeat marketed in Istanbul. Turk. J. Vet. Anim. Sci., 34, 407-412.

Cetin, O., Buyukunal, S.K., Cetin, B. \& Askin, M.V.Z. (2005): Presence of foreign protein in raw and heat treated meat products. Indian Vet. J., 82, 870-872.

EC (2002): Regulation laying down the general principles and requirements of food law, establishing the European food safety authority and laying down procedures in matters of food safety. The European Parliament and of the Council of European Union, 178/2002.

Günş̧en, U., AYdin, A., OvALI, B. \& CoşKUn, Y.I. (2006): Çiğ et ve 1sıl işlem görmüş et ürünlerinde ELISA tekniği ile farkl1 et türlerinin tespiti (Detection of different meat species in raw meat and cooked meat products using ELISA technique). J. Fac. Vet. Med. Istanbul Univ., 32(2), 45-52.

GürBüz, Ü. (2009): Mezbaha bilgisi ve pratik et muayenesi (Theoretical and practical slaughterhouse meat inspection). (1 $1^{\text {st }}$ ed.), Selçuk Üniversitesi Basımevi, Konya, 256 pages.

Hsien, H.M., Tsai, C.C., Tsai, L.C., Chiang, H.L., Huang, N.E., Shih, R.T.P., Linacre, A. \& Lee, J.C.I. (2005): Species identification of meat products using the cytochrome b gene. J. Forensic Sci., 4, 29-36.

ILHAK, O. \& ARSLAN, A. (2007): Identification of meat species by polymerase chain reaction (PCR) technique. Turk. J. Vet. Anim. Sci., 31, 159-163.

Karakuş, K., Aygün, T. \& Alarslan, E. (2008): Gaziantep İli Merkez İlçede Kırmızı Et Tüketim Alışkanlıkları (Consumption habits of meat in centre town of Gaziantep province). YYUJ. Agr. Sci., 18(2), 113-120.

Kesmen, Z., Sahin, F. \& Yetim, H. (2007): PCR assay for the identification of animal species in cooked sausages. Meat Sci., 77, 649-653.

Mane, B.G., Mendiratta, S.K. \& Tiwari, A.K. (2009): Polymerase chain reaction assay for identification of chicken in meat and meat products. Food Chem., 116, 806-810.

Matsunaga, T., Chikuni, K., Tanabe, R., Muroya, S., Shibata, K., Yamada, J. \& Shinmura, Y. (1999): A quick and simple method for the identification of meat species and meat products by PCR assay. Meat Sci., 51, 143-148.

Montowska, M., Rao, W., AleXander, M.R., Tucker, G.A. \& BarRett, D.A. (2014): Tryptic digestion coupled with ambient desorption electrospray ionisation and liquid extraction surface analysis mass spectrometry enabling identification of skeletal muscle proteins in mixtures and distinguishing between beef, pork, horse, chicken, and turkey meat. Anal. Chem., 86, 4479-4487.

Özpinar, H., Tezmen, G., GöKçe, I. \& Tekiner, I.H. (2013): Detection of animal species in some meat and meat products by comparatively using DNA microarray and real time PCR methods. Kafkas Univ. Vet. Fak. Derg., 19(2), 245-252.

Partis, L., Croan, D., Guo, Z., Clark, R., Coldham, T. \& Murby, J. (2000): Evaluation of DNA fingerprinting method for determining the species origin of meats. Meat Sci., 54, 369-386.

TFC (2012): Turkish Food Codex. Regulations on fresh meat, prepared meat and prepared meat mixtures. Official Gazette, Issue 28448, Ministry of Agricultural and Rural Affairs, Ankara, 74/2012.

TÜRKYILMAZ, Ö. \& IRMAK, H. (2008): Et ve et ürünlerinde ELISA tekniği ile türlerin tespiti (Determination of species in meat and meat products with ELISA technique). J. Bornova Vet. Cont. Res. Inst., 30(44), 27-31.

Von Bargen, C., Dojahn, J., Waidelich, D., HumpF, H.U. \& Brockmeyer, J. (2013): New sensitive high-performance liquid chromatography-tandem mass spectrometry method for the detection of horse and pork in halal beef. J. Agr. Food Chem., 61, 11986-11994.

Woolfe, M. \& Primrose, S. (2004): Food forensics: using DNA technology to combat misdescription and fraud. Trends Biotechol., 22, 222-226.

Yildiz, A., Karaca, T., ÇAKmak, Ö., YöRÜK, M. \& BașKaYA, R. (2004): İstanbul'da Tüketime Sunulan Köftelerin Histolojik, Mikrobiyolojik ve Serolojik Kalitesi (The histological, microbiological and serological quality of meatball marketed in Istanbul). YYU Vet. Fak. Derg., 15, 53-57. 